\title{
INTS4 wt Allele
}

National Cancer Institute

\section{Source}

National Cancer Institute. INTS4 wt Allele. NCI Thesaurus. Code C114584.

Human INTS4 wild-type allele is located in the vicinity of 11q14.1 and is approximately $116 \mathrm{~kb}$ in length. This allele, which encodes integ rator complex subunit 4 protein, plays a role in small nuclear RNA transcription. 